\title{
Prevalence of Anaemia and Problems during Menstruation among Adolescent Girls
}

\author{
P. Reka ${ }^{1 *}$, K. P. Vasantha Devi ${ }^{2}$ and A. Thahira Banu ${ }^{3}$ \\ 'Ph.D Scholar, Department of Home Science, Gandhigram Rural Institute, Dindigul District, Tamilnadu, India; \\ reka.vijivelu@gmail.com \\ 2Professor, Department of Home Science, Gandhigram Rural Institute, Dindigul District, Tamilnadu, India; \\ kpvasanthadevi@gmail.com \\ ${ }^{3}$ Assistant Professor, Department of Home Science, Gandhigram Rural Institute, Dindigul District, Tamilnadu, India; \\ thaaze@gmail.com
}

\begin{abstract}
India has the world's highest prevalence of iron deficiency anemia among adolescent girls, with 60 to 70 percent of the adolescent girls being anemic. Adolescence is considered as a nutritionally critical period of life. Hence, the health of adolescent girls demands special attention. So the purpose of the present study was to determine the prevalence of anemia and collect information regarding obstetrical details and psychological problem during menstruation in school going adolescent girls of Gandhigram. School going adolescent girls in the age group of 12-15 years studying in Gandhigram, were selected for the study. Hemoglobin concentration of the blood was analyzed and categorized. Interview schedule was formulated to collect information regarding obstetrics detail and psychological problems during menstruation. Eighty nine percent of adolescent girls were anemic and 74 percent of them had problem during menstruation and most of the girls had psychological problem during menstruation. The study concludes that a high prevalence of anemia was found among adolescent girls. There is a need to improve their hemoglobin status through dietary modification, dietary supplementation and nutrition education.
\end{abstract}

Keywords: Adolescent, Anemia, Menstruation, Psychological Problem

\section{Introduction}

Adolescence is a significant period of human growth and maturation. It is the most vulnerable stage from the point of view of health [1]. World's adolescent population is facing a series of serious nutritional challenges which are not only affecting their growth and development but also their livelihood as adults[2].

World Health Organization estimated that iron deficiency anaemia is a public health problem affecting two million people worldwide and more in developing countries like India [3]. Iron deficiency anaemia affects over $60 \%$ of the adolescent girls in India [4].
Studies have pointed out that iron requirements increased during adolescence, low bioavailability of iron from diets, infections, diseases and parasitic infestations cause iron loss [5], [6]. Apart from low haemoglobin count, there are other indicators of health which vary with nutritional status. The age of onset of menarche has also been found to vary according to nutritional status. As the nutritional status improves the age at menarche is lowered. The relationship between nutritional status and age of menarche has been established in many studies [7-9].

Anemia may also impair concentration, attention span and educational attainment, decreased work efficiency

${ }^{*}$ Author for correspondence 
and physical stamina and increase the risk of infection and mortality [10]. Iron deficiency results in impairments in immune, cognitive and reproductive functions as well as work performance. Head ache, significant pallor of eye lids, tongue, nail beds and palms and fatigue [11]. The study was planned to assess the prevalence of anaemia among adolescent girls and to collect the information related to psychological problems during menstruation.

\section{Materials and Methods}

This was a clinical study among sample of 100 adolescents aged 12-15 years randomly selected in Gandhigram, Dindigul district. An interview schedule was formulated to collect information regarding the socio economic status, age, occupational status, and income of the head of the family, obstetrics details age at menarche, use of sanitary napkins, duration of flow, napkins used per day and cycle length. This schedule also includes details of the menstrual problem such as dysmenorrhoea, irregular menstruation, excessive bleeding, premenstrual syndrome, irritation, leg pain, heaviness in breast and psychological problem like stress, anger, depression, anxiety, poor concentration, palpitation and breathlessness during menstruation.

All the selected subjects were estimated for the haemoglobin concentration of the blood using Cyanmet haemoglobin method. The subjects were categorized as mild, moderate and severe anaemia as per the classification given by Indian Council of Medical Research [12].

\section{Results and Discussion}

A total of 100 adolescent girls participated in the study. The age ranged from 12-15 years. About 48 percent of the girls belonged to 13 years followed by 8,17 and 28 percent of the girls in 12, 14 and 15 years respectively. Sixty seven percent of the subject's fathers were coolies, 31 percent of them were farmers and only 2 percent of them were Government employees. Economic status of the families was expressed on the basis of monthly income of the family. The study revealed that 48 percent of the subjects had income less than Rs. 4500 per month, income of 36 percent were between Rs. 4501-Rs. 7500 per month and 16 percent had above Rs. 7500 per month.

Overall the prevalence of anaemia in the study group was 89 percent. Majority (63 percent) were found to have moderate anaemia with mean value $8.36 \pm 0.62$. Twenty two and 4 percent of the subjects had mild and severe anaemia with mean value of $10.7 \pm 0.47$ and $6.8 \pm$ 0.081 respectively. Only 11 percent were normal and had haemoglobin level of $>12 \mathrm{~g} / \mathrm{dl}$ with mean value of $12.8 \pm$ 0.19 (Table 1).

Table 1. Distribution of the selected adolescent girls based on anaemia

$(\mathrm{N}=100)$

\begin{tabular}{|c|c|c|}
\hline Particular & Percentage & $\begin{array}{c}\text { Haemoglobin Mean } \pm \\
\text { SD }(\mathbf{g} \%)\end{array}$ \\
\hline Normal $(>12 \mathrm{~g} \%)$ & 11 & $12.08 \pm 0.019$ \\
\hline Mild $(10-11.9 \mathrm{~g} \%)$ & 22 & $10.70 \pm 0.047$ \\
\hline Moderate $(7-9.9 \mathrm{~g} \%)$ & 63 & $08.36 \pm 0.062$ \\
\hline Severe $(<7 \mathrm{~g} \%)$ & 04 & $06.08 \pm 0.081$ \\
\hline
\end{tabular}

The obstetrics detail of the selected subjects revealed that 92 per cent of the girls attained menarche from 11 to 15 years of age. All of them used sanitary napkins. Most of the subjects used more than three sanitary napkins per day during menstruation.

Table 2. Details of the selected adolescent girls

$(\mathrm{N}=100)$

\begin{tabular}{|c|c|c|c|}
\hline Particulars & Percentage & Particulars & Percentage \\
\hline Puberty Attained & & Napkins used per day & \\
\hline Yes & 92 & 2 pads & 11 \\
\hline No & 08 & 3 pads & 43 \\
\hline & & $>3$ pads & 46 \\
\hline Age at menarche & & Cycle length & \\
\hline 11 & 4 & $<20$ days & 22 \\
\hline 12 & 24 & $>30$ days & 78 \\
\hline 13 & 34 & & \\
\hline 14 & 21 & & \\
\hline 15 & 09 & Menstrual problem & \\
\hline $\begin{array}{c}\text { Use of Sanitary } \\
\text { Napkins }\end{array}$ & - & Yes & 74 \\
\hline Cloth & 92 & No & 26 \\
\hline Napkins & & $\begin{array}{c}\text { Problems during menstru- } \\
\text { ation }\end{array}$ & \\
\hline Duration of flow & & $\begin{array}{c}\text { Problems during menstru- } \\
\text { ation }\end{array}$ & \\
\hline 2 days & 7 & Dysmenorrhoea & 70 \\
\hline 3 days & 67 & Irregular menstruation & 39 \\
\hline 3-5 days & 26 & Excessive bleeding & 54 \\
\hline & & Premenstrual syndrome & 67 \\
\hline & & Irritation & 32 \\
\hline & & Leg pain & 36 \\
\hline & & & 27 \\
\hline
\end{tabular}

From the selected subjects, 93 percent of the adolescent girls attained menarche, 74 percent had problem during menstruation. Most common complaint was dysmenorrhoea (70 percent) followed by premenstrual 
syndrome (67 percent), excessive bleeding (54 percent), irregular menstruation (39 percent), irritation (32 percent), leg pain (36 percent) and heaviness in breast (27 percent) (Table 2 ).

Most of the subjects had psychological problem during menstruation. Most common complaint was stress (56 percent) followed by palpitation (50 percent), anger (46 percent), breathlessness (30 percent) depression (28 percent),poor concentration (28 percent) anxiety (17 percent) (Table 3 ).

Table 3. Psychological problems of the selected adolescent girls

$(\mathrm{N}=100)$

\begin{tabular}{|c|c|}
\hline Particulars & Percentage \\
\hline Stress & 56 \\
\hline Anger & 46 \\
\hline Depression & 28 \\
\hline Anxiety & 17 \\
\hline Poor concentration & 28 \\
\hline Palpitation & 50 \\
\hline Breathlessness & 30 \\
\hline
\end{tabular}

The overall prevalence of anaemia was found to be 89 percent, of which 4 percent were severely anaemic, 63 per cent suffered from moderate anaemia and 22 percent were mildly anaemic. Similar prevalence is reported by Bulliyy et al [13] which stated 96.5 percent prevalence among non - school going adolescent girls, of which 45.2, 46.9, 4.4 percent had mild, moderate and severe anaemia respectively. Study conducted by Kalpana et al [14] among adolescent girls (13- 15 years) in Coimbatore, Tamilnadu reported that 76.4 percent of adolescent girls were anaemic.

According to Dasgupta and Sarkar [15], mean age of menarche in adolescent girls was 12.8 yrs, whereas Khanna et al [16] reported that the mean age of menarche was 13.2 yrs. In the present study mean age of menarche is $12.03 y r$. Mittal et al [17] reported that 60.93 percent had problem during menstruation and the most common complaint was dysmenorrhoea (58.7 percent). The findings of the present study showed that 70 per cent had the problem of dysmenorrhoea. Comparatively higher prevalence of dysmenorrhoea has been reported in a study by Anil and Anju [18], (79.67\%) and Sundel et al [19], (67\%). Rajni Dihngre [1] reported that among the selected 200 adolescent girls in Jammu district 64.5 percent had complaint of palpitation, 89.5 percent had general weakness and 16 percent had complained of dizziness. Thus these problems are common to adolescents during menstruation.

\section{Conclusion}

The study concludes that anaemia was common among young girls and menstrual and psychological problems during menstruation was also reported. Anaemia may also impair concentration and decrease the work efficiency of the affected individuals.

\section{References}

1. Rajni D., "An Assessment of Health Status of Adolescent Gujjar Tribal Girls of Jammu District", Stud Tribes Tribals, vol. 9(2), p. 133-138, 2011.

2. Balasubramanian P., "Health needs of poor unmarried adolescent girls. A community based study in rural Tamil Nadu", Indian Journal of Population Education, vol. 28(29), p. 18-33, 2005.

3. Lokeshwar M. R., and Metha., "Prevention of iron deficiency anaemia: How far have we reached", Indian J pediatr, vol. 23, p. 45-53, 2010.

4. 2012 WHO Micronutrient Deficiencies. Retrieved from http://www.who.int/nutrition/topics/ ida/en/index.html

5. Brabin L., and Brabin B. J., "The cost of successful adolescent growth and development in girls in relation to Iron and Vitamin A Status", Am Journal of Clinical Nutrition, vol. 55, p. 955-958, 1992.

6. Kanani S., and Ghanekar J., "Anaemia and the Adolescent Girl: A Review of Some Research Evidence and Inter-venations Strategies", Department of Foods and Nutrition. M.S. University of Varoda and UNICEFF, India. 1997.

7. Abioye-Kuteji E. A., Ojofeitimi E. O., Aina O. I., Kio F., and Alukoy M. O., "The influence of socio-economic and nutritional status on menarche in Nigerian school girls", Nutritional Health, vol. 11(3), p. 185-195, 1999.

8. Acharya A., Reddaiah U. P., and Baridalyne N., "Nutritional status and menarche in adolescent girls in an urban resettlement colony of South Delhi", Indian Journal of Community Medicine, vol. 31(4), p. 10-12, 2006.

9. Acharya V., Reddaiah., and Baridalyne N., "Nutritional Status and Menarche in Adolescent Girls in an Urban Resettlement Colony of South Delhi", Indian Journal of Community Medicine, vol. 31(4), p. 302-303, 2006.

10. Lokeshwar, M. R., Metha. "Prevention of iron deficiency anaemia: How far have we reached", Indian J pediatr, vol. 23, p. 45-53, 2010.

11. Mohammad M. M., "Prevalence of iron deficiency anaemia among school children in select district", Masters dissertation, Annajah National University, Nablus, Palestine. 2006

12. ICMR, Micronutrient deficiency disorders in 16 districts of India. Part -I Report of an ICMR Task force study District Nutrition Project, New Delhi, 2001.

13. Bulliyy G., Mallick G., Seth G. S., and Kar S. K., "Haemoglobin status of non school going girls in 3 districts of Orissa", Int J Adolescent Med Health., vol. 19, p. 395-406, 2007.

14. Kalpana, C. P., Aruna N., and Thangarathi., "Effect of me- 
dicinal iron supplementation and nutrition education on anaemic adolescent girls of low income families", The Indian Journal of Nutri and Diete, vol. 44, p. 551-559, 2007.

15. Dasgupta A., Sarkar S., "Menstrual Hygiene: how hygienic is the adolescent girl: a study of adolescent girls in West Bengal”, Indian J Community Medicine, vol. 33, p. 77-80, 2008.

16. Khanna A., Goyal R. S., and Bhawsar R., "Menstrual practices and reproductive problems: a study of adolescent girls in Rajasthan", J Health Manag, vol. 7, p. 91-107, 2005.
17. Mital.P, Bala D. V., Hemant T. A., "Study of nutritional status and high risk behavior of adolescents in Ahmedabad: A Cross Sectional Study", Health line, vol. 2(1), p. 21-27, 2011.

18. Anil K., Agrawal, and Anju Agrawal A., "Study of dysmenorrhea during menstruation in adolescent girls", Indian J Community Medicine, vol. 35, p. 159-164, 2010

19. Sundell G., Milsom I., Andersch B., "Factors influencing the prevalence and severity of dysmenorrhea in young women", Br. J Obstetric Gynaecol., vol. 97, p. 588-594, 1990. 